\title{
RETAILERS' PERCEPTION TOWARDS PRODUCT DEMAND AND SALES DURING THE PANDEMIC PERIOD OF COVID19
}

\author{
Suraj Palod, Shri Ramdeobaba College of Engineering and Management \\ Mitali Singh, Shri Ramdeobaba College of Engineering and Management \\ Dr. Gayathri Band, Shri Ramdeobaba College of Engineering and Management
}

\begin{abstract}
FMCG sector is the 4th largest sector of the Indian economy. The purpose of this study is to analyse the change in sale of various commodities and change in purchase of consumers through retailer's perception during the pandemic COVID 19. In a shot to slow the unfold of virus, several countries have obligatory temporary closures to non-essential stores, bars and venues likewise as put a ban on massive public gatherings. As such, the marketplace for FMCG faces sizable changes and changes in demand for client grocery (CPG).

The study focuses primarily on the retailer perception of consumers and market behaviour towards choose fast paced trade goods. Total of 120 forms were collected using Random sampling. A logistic Regression was used to identify the factors which have an effect in the retailers' business during this pandemic situation. The four most important factors that are important for the retail outlets to survive in the pandemic situations are Quality of supply, Years of existence, delivery services avialable and product demand. In food and beverages, staples has the highest demand, in home care the toilet care has the highest demand and in personal care hand sanitizer has the highest demand. We also find a change in trend of purchase by the consumers, where consumers prefer larger quantity purchase and monthly purchase instead of frequent or fortnightly purchases.

Keywords: FMCG, Retail Perception, food \& beverages, home care, personal care, logistic regression
\end{abstract}

Article Received: 10 August 2020, Revised: 25 October 2020, Accepted: 18 November 2020

\section{INTRODUCTION:}

The world is currently experiencing a pandemic due to highly infectious viruses known as Corona Virus or COVID-19. In an attempt to slow the spread of virus, many countries have imposed temporary closures to non-essential stores, bars and venues as well as putting a ban on large public gatherings and encouraging people to work from home wherever possible. As such, the market for FMCG faces considerable charges, demand for Consumer Packaged Goods (CPG) has climbed sharply in heavily-affected countries, while growth in household goods spending surged as well. Oneway people try to reduce their chances of catching the virus is by decreasing the frequency of going to the grocery store. Some consumers are resorting to stock piling water and food while others are using E-Commerce to purchase products that they usually would find in a store. The outbreak of Corona Virus has contributed to an increased demand for fast moving products. After analyzing sales in the tenth week of 2020 , the growth for entire FMCG shopping basket amounted to $13 \%$ compared to same period last year. Antibacterial gel, sanitizers was the most popular hygiene product to buy, while rice achieved the highest sales growth in the food category. Retailer revenue will be negatively impacted, or in a few cases positively affected, depending on the situation. Grocery retail chains such as Walmart and target have seen an increase in revenues as customers are stocking up on groceries and personal care products. Supermarkets have braced for stockpiling of corona virus panic escalates. Makers of food, beverages, health and personal care products are seeing a bump in sales as consumers stock up on personal care products and emergency food rations. An unprecedented spike in demand for grocery and household products has created during the unfortunate spread of COVID-19 virus, as consumers prepare for weeks (maybe months) of 
school closures, work from home and restaurant closures. Walmart which features a market price of about $\$ 348$ billion, may be a beneficiary of consumers flooding its stores and stocking abreast of home items, like toilet paper, cleaning supplies and food.

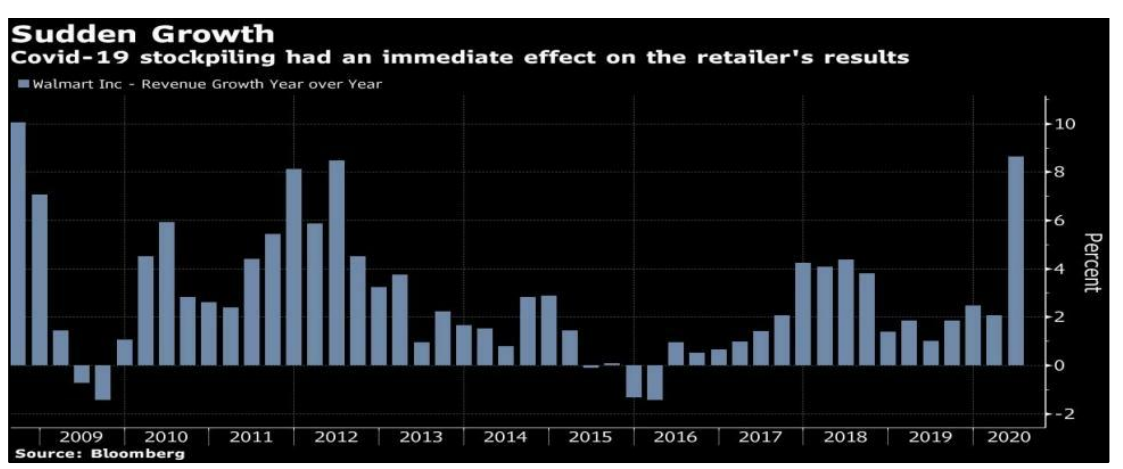

India's biggest consumer goods companies are ramping up production to meet the steep rise in demand with people rushing to stock up on essentials and groceries in bulk amid fears of a lockdown due to corona virus outbreak as several states imposed stringent curbs on movement. This marks a reversal of last years' fortunes when companies cut production because of weak consumptions across segments. Parle-G records its best ever sales during lockdown. It achieved a unique milestone of selling the maximum number of biscuits during lockdown breaking the record of
82 years as Parle-G brand is in production since 1938. Although the biscuit maker didn't reveal its official sales figures, it clocked record breaking sales during March, April \& May months. They have grown their overall market share by nearly $5 \%$ $\& 80-90 \%$ of this growth has come from the Parle$\mathrm{G}$ sales. Some of companies like Parle-G also arranged transport for their workers for an easier and safer commute to work. Once these factories were operational, their focus was to produce brands that drove maximum sales.

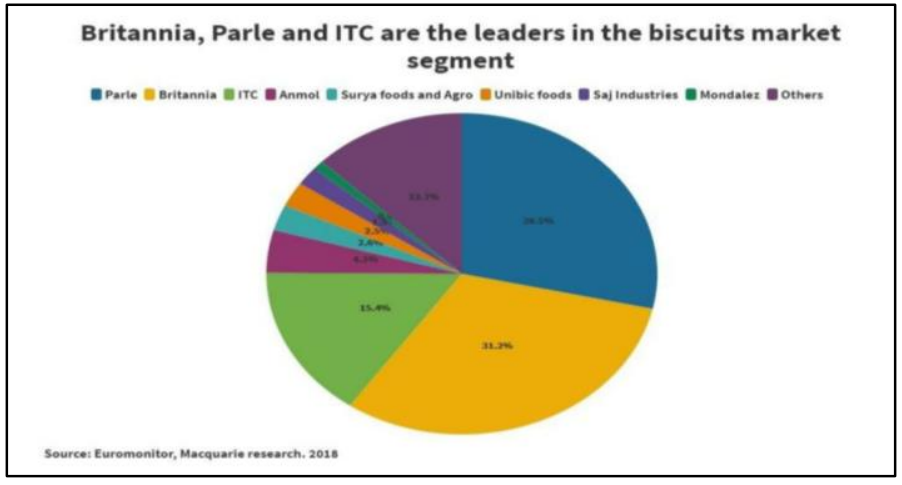

On the other hand, online sales have comparatively increased as customers are buying online rather than leaving the house to go shopping. However, online market places such as Amazon are struggling to bring goods from suppliers overseas.

\section{LITERATURE REVIEW:}

This study presents a review of the literature, within the field of client behavior towards FMCG aid product. Baumgartner (2002) recognized that there's marvelous complication in client behavior. There are also many aspects each rational and
Apart from online sales, COVID-19 will deal a crushing blow to this sector. It remains to be seen how long it will take to recover. Based on impact ratings in each dimension we judge the overall impact on the retail sector as severe.

emotional which will act reciprocally in influencing the acquisition call. Sauer (2001) news on the business trends in aid and cosmetic business, used a classification theme of deodorants, hair care product, color cosmetics, convenience grooming product, oral hygiene product, fragrances, skin care 
product and sun care product. Deliya (2012) importance of packaging style as a vehicle for communication and disapproval is growing in competitive markets for prepacked FMCG product. This analysis used a spotlight cluster methodology to know client behavior towards such product.

Schiffmand et al. (2000) client behavior is within the look for buying, evaluating and confiscating product, and services. They any thoroughbred that the study of client behavior thinks about not solely with what shoppers get, however they get, and the way typically they go. Kotler, (2002) believes that such social factors, reference teams, family and social roles and statues influence consumer's behavior. Perrault et al, (2000) explicit that relationships with different members of the family influence several aspects of client behavior. members of the family can also share several attitudes and values, take into account each body's opinion and divide numerous shopping for tasks. Rasool et al. (2012) conducted to seek out the results of advertisements on user behavior and therefore the results projected that individuals changes their complete for to undertake to new brands.

Kotler et al. (2009) the connection between client behavior and selling strategy is stressed as a result of it depends upon managers' understandings of client behavior. Understanding of client behavior is very necessary in recession times. Hindoo et al (2012) studied the impact of product value and quality on client shopping for behavior. client behavior patterns square measure quite associated with one another, specifically within the aspects like quality, evaluation and higher cognitive process (Kumar, 2011). The results found that quality, satisfaction, styling, price, finishing operation, performance, safety, worth, shape, use and excellence were placed prime priority. Celen et al. (2005) analyzed the structure of the market is being reworked in recent years by new retails formats.

Katiyar, and Nikha Katiyar, (2014) "An Empirical Study of Indian client shopping for Behavior of
FMCG product (With Special Reference of Bathing Soap)", bathing soap square measure fastpaced trade goods that have seen a surge within their sales in the past few decades in Asian country additional and additional individuals square measure gap up to the concept of experimenting and attempting out newer soap. This study is arranging to cowl the varied factors that influence the shopping for call of shoppers World Health Organization attempt to purchase and or used soap. FMCG sector is that the fourth largest sector in Asian country touching everyone life's in each day. The FMCG product sector is important contributor to India's gross domestic product.

Chitra. R (2014) “An empirical study on Customers Purchase Intention towards Branded Apparels", this paper aims to review factors touching purchase intention towards branded attire. Purchase intention is explained in terms of general client variables (normative influence, client confidence) and complete specific variables (perceived quality, emotional value).

Nasrudeen R and Mohamed, (2014) "Level of Consumption of fast-paced trade goods by Rural shoppers - Associate in Nursing Analytical Study", ever since independence of Asian country, attributable to some obvious reasons, selling uninheritable a for the most part urban bias. it had been the revolution within the seventies that provided a much-needed boost to agriculture-based rural economy within the country. afterwards, several companies started showing interest within the rural markets and extend their penetration to achieve smaller village and cities. Further, now-adays rural shoppers square measure behaving like urban shoppers towards the urban modus vivendi, fashion, taste, preferences, etc.

Rajasekaran, B and Saravanan, P. A. (2014) highlighted, "Consumer Satisfaction on fast-paced client Goods". The study throws on the attitudes, values, beliefs and perception of the shoppers with regards to the consumption of fast-paced trade goods. to review the complete preference of fastpaced trade goods, the preference and opinion of 
client towards well-liked brands are taken into thought.

Shanmugapriya .G and Sethuraman .R, (2014) "Consumers' Satisfaction towards Hamam Soap in Thanjavur Town", the selling state of affairs in Asian country has undergone large amendment since 1991 because of the economic reforms. Postliberalization, competition intense in each line and market, that forced brands to redefine their norms of existence all told industries. within the FMCG business, particularly in soap sector there has been severe competition among the MNCs, national and native players. complete loyalty is decided by many distinct psychological processes of the shoppers and entails variable measurements.

Sonia and Garima Dalal, (2014) "To Study the Satisfaction Level of consumers towards the complete of Consumer's product - A Study administered on Rural Masses", The Indian fastpaced trade goods (FMCG) business began to form throughout the last fifty odd years. The FMCG sector could be a corner stone of the Indian economy. This sector touches each facet of human life. Indian FMCG market has been divided for an extended time between the organized sector and therefore the unorganized sector.

The study focuses primarily on the patron behavior towards choose fast-paced trade goods in Nagpur, however with the prevailing trend, it's necessary to target the essence and emergence of vivacious in selling efforts from the FMCG firms. so with additional variety of firms moving into the agricultural and concrete market, with a range of product, it's a requirement for the businesses to review the agricultural and concrete client behavior, on FMCG. This study can highlight the patron behavior before purchase, at the time of purchase, post- purchase and factors influences the patron behavior towards purchase of FMCG product throughout this Corona pandemic amount.

People wearing protective masks shop at Kendriya Bhandar in the wake of coronavirus pandemic. PTI As Covid-19 ravages health systems and economies around the world, the lockdown and its accompanying preventive measures in India have deeply impacted the FMCG (fast-moving consumer goods) industry. Indian retailers suffered a big 71 per cent drop by demand, with no orders received by 95 per cent outlets within the first week of lockdown, consistent with a report by retail intelligence platform Bizom. It did a consumer spend analysis for the unorganized Indian retail sector.

Beverages fared the worst among all the product categories. The category's peak season is summer and just as it was about to start Covid-19 and the lockdown hit the country. The beverages season typically picks up a week or two before Holi. It did not happen because 90 per cent of the people have been 100 per cent of the time indoors during the lockdown. Also, the offtake for carbonated beverages was impacted by low alcohol consumption since the two are usually paired as a drink.

\section{RESEARCH METHODOLOGY:}

The study was conducted among 120 retailers. A random method of sampling was used for data collection. A total of 155 forms were distributed and 120 completely filled forms were used for analysis, an effective percentage of $77.4 \%$. An arbitrary scale questionnaire was designed to study the retailer perception during this pandemic situation in the country.

\section{OBJECTIVE:}

1. To analyze the change in sale of various commodities during Covid 19

2. To identify the keep factors affecting the sales of retailers during Covid 19

3. To analyze change in trend of purchase of consumers through retailer's perception

\section{DATA INTERPRETATION:}

We have conducted a survey among different retailers with the help of questionnaire by which we come to know about following results. We have 
focused on two key points while conducting a survey. They are:

1) Effect on overall sales of the following category of goods due to corona virus pandemic.

2) Increase in demand of various product during this Corona Pandemic.

The three verticals of FMCG sector which we have taken into consideration for our research and survey are Food \& Beverages, Home Care Products and Personal Care Products.

So, we have applied the formula of a weighted mean and the results are presented as below:

Effect on overall sales of the following category of goods due to corona virus pandemic (1-VERY HIGH \& 5-VERY LOW)

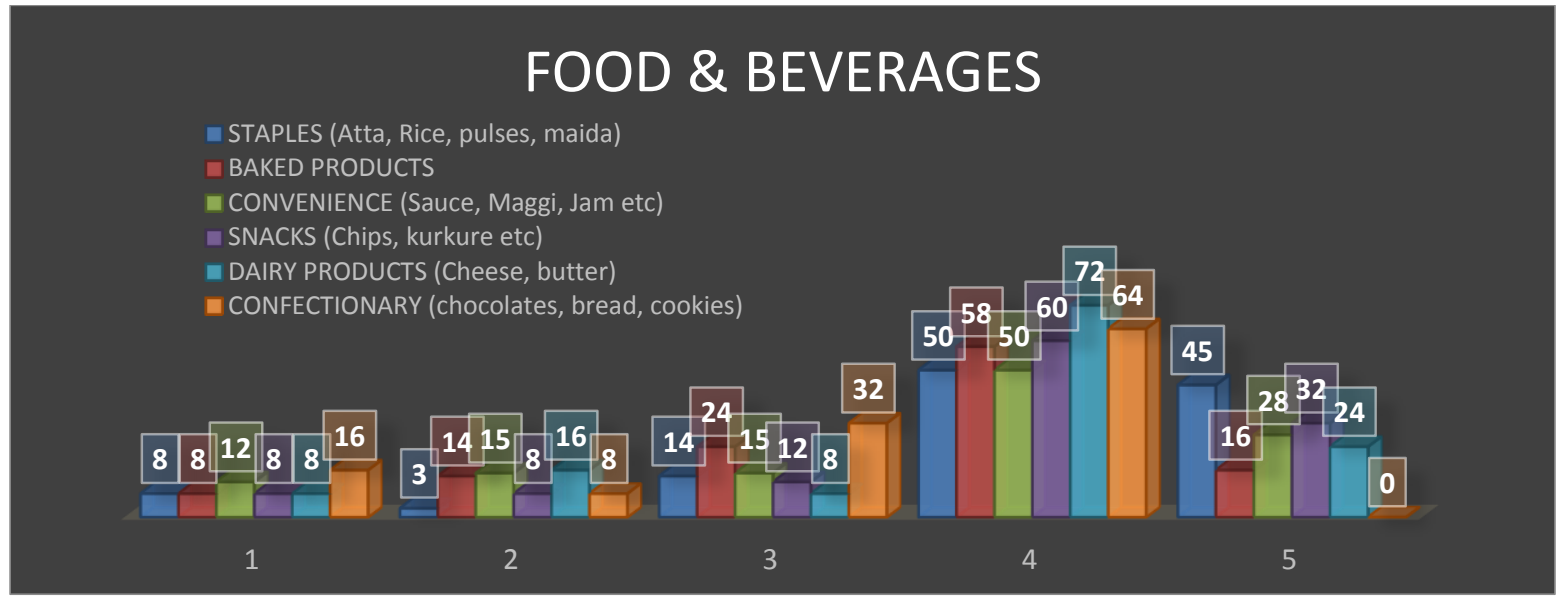

According to the survey done (120 Responses) we have calculated the effect of pandemic on FMCG products by applying weighted mean formula. The highest impact of sales has been by staples (3.94) followed by Dairy products (3.87). Moderate influence in Snacks is third (3.77) followed by Convenience (3.46) and Baked products (3.43). The least impact on sales is by confectionary (3.07).

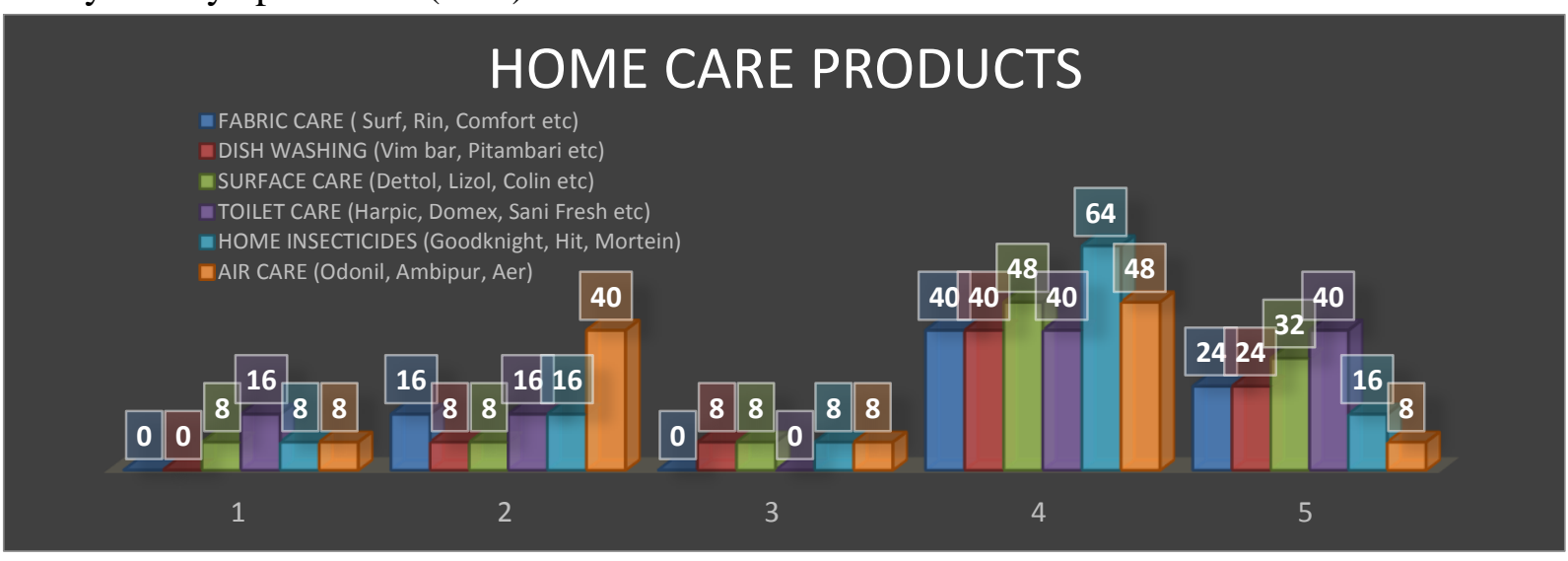

According to the survey done (120 Responses) we have calculated the effect of pandemic on FMCG products by applying weighted mean formula. The highest impact of sales has been by surface care, toilet care and home insecticides (all values at 3.27). Moderate influence in air care (2.80). The least impact on sales is by dish washing (2.68) fabric care (2.60). 


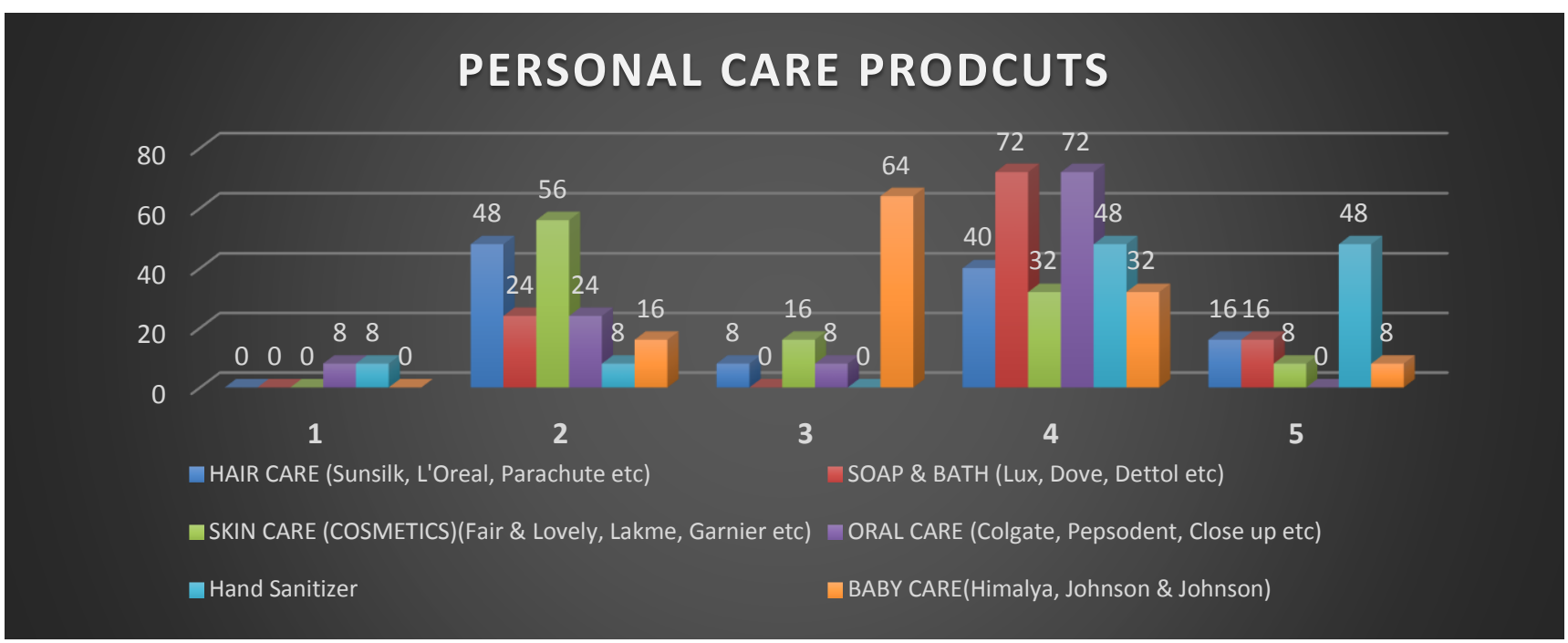

According to the survey done (120 Responses) we have calculated the effect of pandemic on FMCG products by applying weighted mean formula. The highest impact of sales has been by hand sanitizer (3.73) followed by soap and bath (3.47). Moderate influence in baby care (3.27), hair care and oral care (3.00). The least impact on sales is by skin care and cosmetics (2.73).

Rank the following products under each section depending on their increase in demand during this Pandemic coronavirus. (rank 1 - Highest Demand, rank 5 - lowest demand)

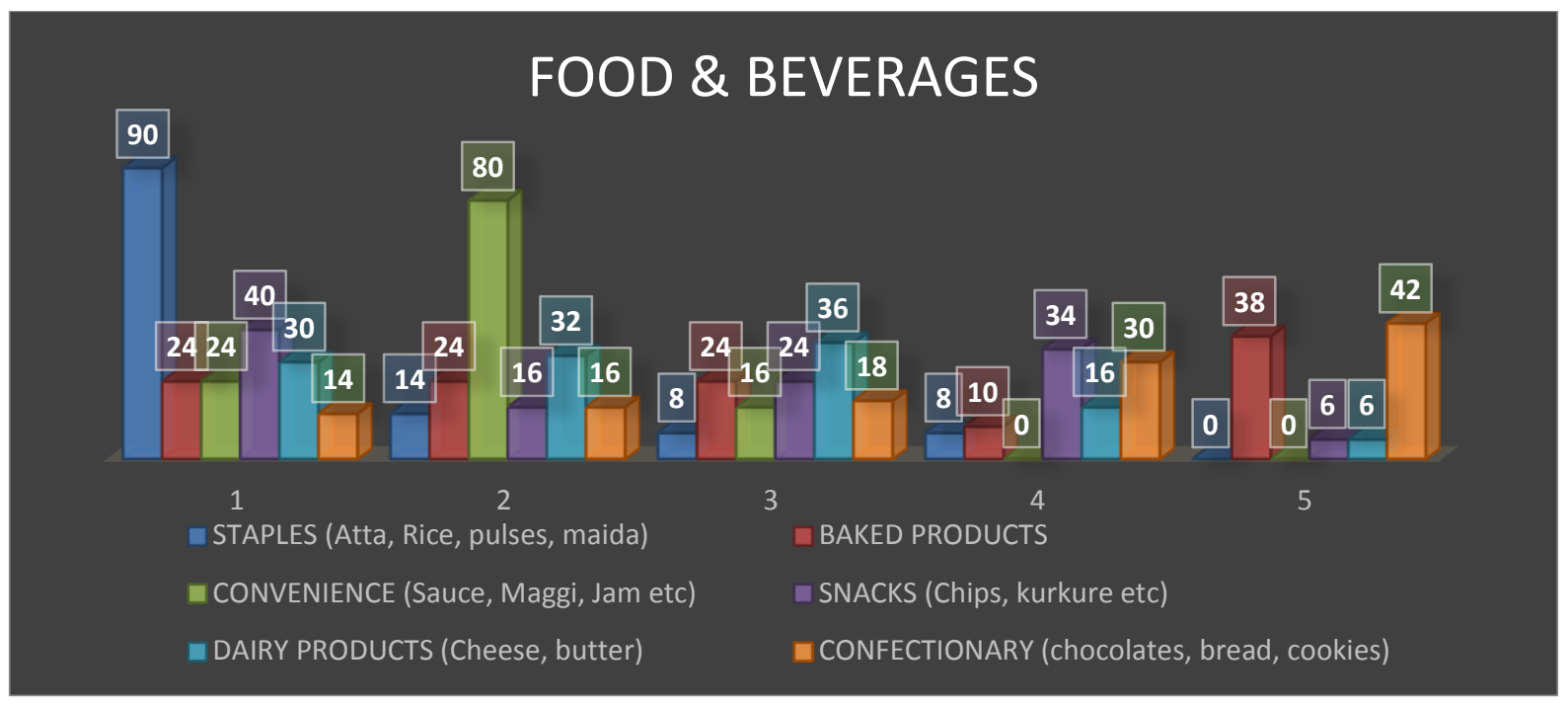

According to the survey done (120 Responses) we have calculated the effect of pandemic on FMCG products by applying weighted mean formula. We have ranked them from Rank 1 to Rank 5 based on the increase in sales during the pandemic period, where rank 1 is the highest rank and rank 5 is the lowest rank. The following are the ranks of sub categories of Food \& Beverages division of FMCG sector.
RANK 1: STAPLES: 4.55

RANK 2: CONVENIENCE: 4.07

RANK 3: DAIRY PRODUCTS: 3.53

RANK 4: SNACKS: 3.42

RANK 5: BAKED PRODUCTS (2.88) AND CONFECTIONARY (2.42) 


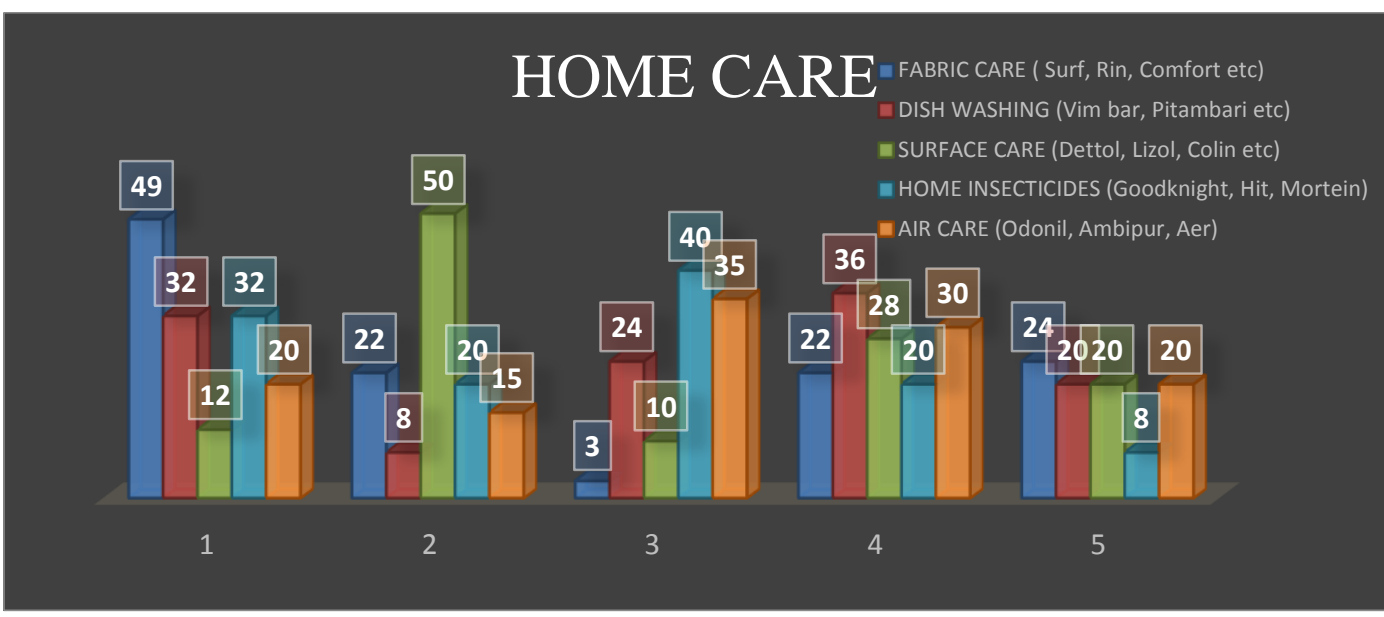

According to the survey done (120 Responses) we have calculated the effect of pandemic on FMCG products by applying weighted mean formula. We have ranked them from Rank 1 to Rank 5 based on the increase in sales during the pandemic period, where rank 1 is the highest rank and rank 5 is the lowest rank. The following are the ranks of sub categories of Home care products division of FMCG sector.

RANK 1: TOILET CARE: 3.92

RANK 2: FABRIC CARE: 3.42

RANK 3: INSECTICIDES: 3.40

RANK 4: DISH WASHING: 2.97

RANK 5: AIR CARE: 2.88

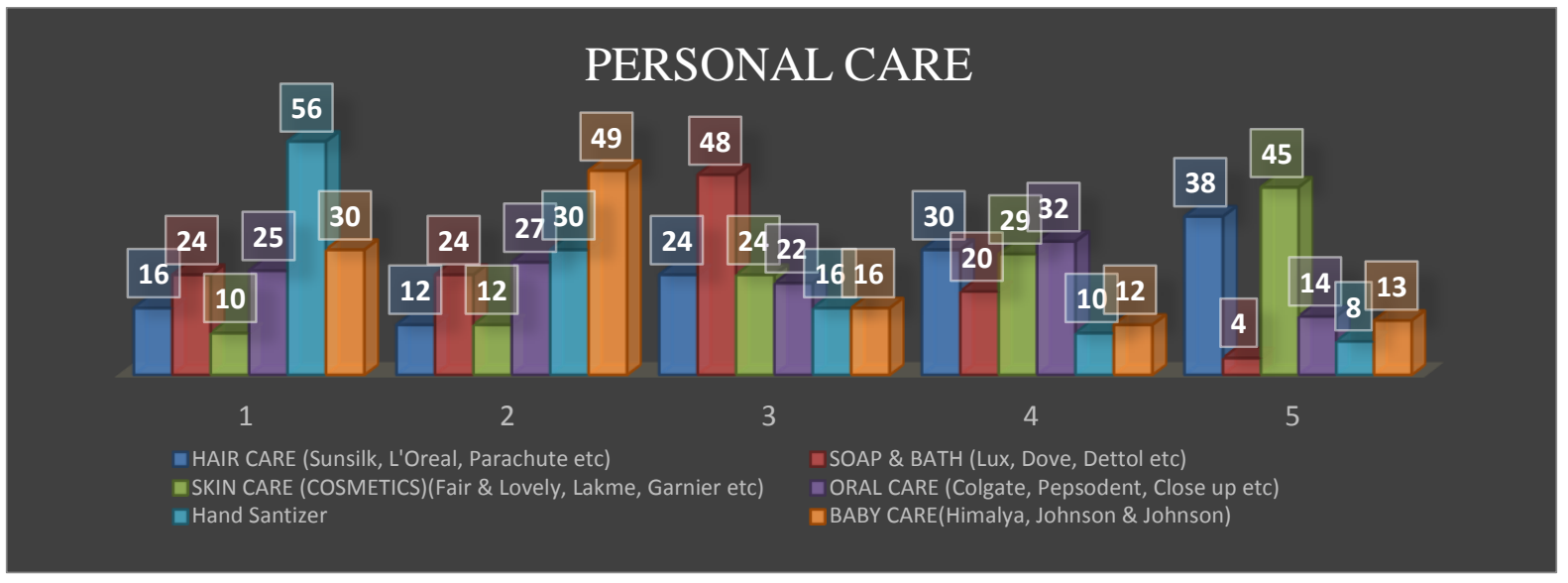

According to the survey done (120 Responses) we have calculated the effect of pandemic on FMCG products by applying weighted mean formula. We have ranked them from Rank 1 to Rank 5 based on the increase in sales during the pandemic period, where rank 1 is the highest rank and rank 5 is the lowest rank. The following are the ranks of sub categories of Personal care products division of FMCG sector.

RANK 1: HAND SANITIZER: 3.97

RANK 2: BABY CARE: 3.59

RANK 3: SOAP \& BATH: 3.37

RANK 4: HAIR CARE: 2.48

RANK 5: COSMETICS: 2.28

\section{DATA ANALYSIS:}

Logistic regression is used to predict a categorical (usually dichotomous) variable from a set of predictor variables. With a categorical dependent variable, discriminant function analysis is usually employed if all of the predictors are continuous; logit analysis is usually employed if all of the predictors are categorical; and logistic regression is often chosen if the predictor variables are a mix of continuous and categorical variables.

For a logistic regression, the predicted dependent variable is a function of the probability that a 
particular subject will be in one of the categories (for example, the probability that the store has the effected or not effected by Pandemic COVID 19, given set of scores on the predictor variables). The predictor variables considered for the study are number of years of existence, type of outlet, quality of supply, product demand, company/ brand reputation, delivery, credit facility, shelf life/ exchange.

\begin{tabular}{|c|c|}
\hline \multicolumn{2}{|c|}{ Dependent Variable Encoding } \\
\hline Original value & Internal Value \\
\hline No Effect & 0 \\
\hline Effect & 1 \\
\hline
\end{tabular}

\begin{tabular}{|c|c|c|c|c|c|}
\hline \multicolumn{6}{|c|}{ Classification Table $^{\mathrm{a}, \mathrm{b}}$} \\
\hline \multirow{2}{*}{\multicolumn{3}{|c|}{ Observed }} & \multicolumn{3}{|c|}{ Predicted } \\
\hline & & & \multicolumn{2}{|c|}{ decision } & \multirow{2}{*}{$\begin{array}{c}\text { Percentage } \\
\text { Correct }\end{array}$} \\
\hline & & & Effect & No_Effect & \\
\hline \multirow{2}{*}{ Step 0} & \multirow{2}{*}{ decision } & Effect & 72 & 0 & 60 \\
\hline & & No_Effect & 48 & 0 & 40 \\
\hline \multicolumn{3}{|c|}{ Overall Percentage } & & & 60 \\
\hline \multirow{2}{*}{ Step 1} & \multirow{2}{*}{ decision } & Effect & 62 & 15 & 80.5 \\
\hline & & No Effect & 16 & 27 & 62.8 \\
\hline \multicolumn{3}{|c|}{ Overall Percentage } & & & 74.17 \\
\hline \multicolumn{6}{|c|}{ a Constant included in the model } \\
\hline \multicolumn{3}{|c|}{$\mathrm{b}$ The cut value is .500} & & & \\
\hline
\end{tabular}

- Observed - This indicates the number of 0 's and 1's that are observed in the dependent variable.

- Predicted - These are the predicted values of the dependent variable based on the full logistic regression model. This table shows how many cases are correctly predicted ( 72 cases are observed to be 1 and are correctly predicted to be $1 ; 48$ cases are observed to be 0 and are incorrectly predicted to be 1 for step 0.62 cases are observed to be 1 and are correctly predicted to be $1 ; 27$ cases are observed to be 0 and are correctly predicted to be 0 for step 1), and how many cases are not correctly predicted (16 cases are observed to be 0 but are predicted to be 1 ; 15 cases are observed to be 1 but are predicted to be 0 ).

- Overall Percentage - This gives the overall percent of cases that are correctly predicted by the model. This percentage has increased from 60.00 for the null model to 74.17 for the full model.

\begin{tabular}{|c|c|c|c|c|c|c|c|c|}
\hline \multicolumn{9}{|c|}{ Variables not in the Equation } \\
\hline & & & B & SE & Wald & df & Sig. & $\operatorname{Exp}(B)$ \\
\hline \multirow[t]{5}{*}{ Step 1} & \multirow[t]{5}{*}{ Variables } & Years & -1.985 & .577 & 11.83 & 1 & .000 & 7.279 \\
\hline & & Outlet & .058 & .242 & 0.057 & 1 & .283 & 1.059 \\
\hline & & Supply & 2.123 & .539 & 15.513 & 1 & .000 & 8.356 \\
\hline & & Demand & 1.324 & .423 & 9.797 & 1 & .003 & 3.758 \\
\hline & & Brand & .098 & .443 & 0.048 & 1 & .123 & 1.102 \\
\hline
\end{tabular}




\begin{tabular}{|l|l|r|r|r|r|r|r|} 
& Delivery & 1.656 & .497 & 11.102 & 1 & .002 & 5.238 \\
\cline { 3 - 8 } & Credit & 1.023 & .387 & 6.987 & 1 & .004 & 2.781 \\
\cline { 3 - 8 } & Shelf & .784 & .532 & 2.171 & 1 & .067 & 2.190 \\
\cline { 3 - 8 } & Constant & 6.231 & 1.234 & 25.496 & & .000 & \\
\hline
\end{tabular}

$p$ is the probability of being affected because of present pandemic situation. Expressed in terms of the variables used in this example, the logistic regression equation is:

$\log (\mathrm{p} / 1-\mathrm{p})=6.231+1.985($ Year $)+.058$ $($ Outlet $)+2.123$ (Supply) + 1.324 (Demand) + 0.098 (Brand) +1.656 (Delivery) $+\mathbf{1 . 0 2 3}$ (Credit) + 0.784 (Shelf)

These estimates tells about the relationship between the independent variables and the dependent variable, where the dependent variable is on the logit scale. These estimates tell the amount of increase (or decrease) in the predicted $\log$ odds of effect $=1$ that would be predicted by a 1 unit increase (or decrease) in the predictor, holding all other predictors constant. Because these coefficients are in log-odds units, they are often difficult to interpret, so they are often converted into odds ratios as shown in $\exp (\mathrm{b})$ column at the end of the table.

\section{CONCLUSION:}

The four most important factors that are important for the retail outlets to survive in the pandemic situations are Quality of supply, Years of existence, delivery services avialable and product demand. The current business environment is becoming increasingly uncertain, unpredictable, and competitive as a result increasingly more complex. In today's context flexibility in supply chains allows firms to grow at rapid rate, make reach to maximum number of customers and helps in avoiding any future disruption. The main reason of acquiring flexibility concepts in Indian FMCG industry is customer highly volatile demand. Retailers prefer stocking products in higher demand and they require a higher credit for stocking. FMCG companies have to enhance their delivery and supply capabilities in markets as the demand for their products increases. In a way, it means that an FMCG company may have to enhance their distribution network as demand for its products increases. It is also found that with an increasing demand for a product, retailers seem to expect a higher amount and period of credit from their suppliers. Years of existence is another important factor that influenced the given situation. It was noticed that those retail outlets which had an existence in the market for 10-12 years or more were less effected as compared to the retail outlets which were less tha 10 years old. Though the pandemic situation has an overall effect on the market, but retail outlets having larger years of existence were able to sustain the pandemic situation. The products or brands which had a good supply chain and availability of the products at the right place and right time were able to generate effective sales and earnings. Owning to lockdown there was a demand for higher quantity packaging products as people avoided coming to stores often. Most of the retail outlets also provided the home delivery and credit facility to their customers. Home care and hygiene products, staple and dairy products were in high demand during this period of pandemic.

\section{REFERENCES:}

[1] Ankit Katiyar, and Nikha Katiyar, "An Empirical Study of Indian Consumer Buying Behavior of FMCG Products (With Special Reference Of Bathing Soap)", International Journal of Management and Commerce Innovations, Vol. 2, ISSN 23487585, Issue 1, 2014, pp.211-217.

[2] Celen, A., Erdogan, T. and Taymaz, E. (2005), "Fast Moving Consumer Goods Competitive Conditions and Policies", 
ERC Working Papers in Economics 05/03, Economic Research Center, Middle East Technical University, Anakara, Turkey.

[3] Chitra .R “ An empirical study on Customers Purchase Intention towards Branded Apparels", Indian Journal of Research in Management, Business and Social Sciences (IJRMBSS), Vol. 2, ISSN No. : 2319-6998, Issue 1, Jan. 2014, pp.46-49.

[4] Deliya, M. (2012), "Consumer Behavior towards the New Packaging of FMCG Products", Abhinav National Monthly Referred Journal of Research in Commerce \& Management, Vol. 1 (11), pp.199-211.

[5] Deliya, Mitul \& Parmar, Bhavesh. (2012). Role of packaging on consumer buying behavior--Patan district. Global Journal of Management and Business Research.

[6] Kotler, P. (2002), "Marketing Management", The Millennium Edition, New Delhi, Prentice-Hall of India, pp.15984

[7] Kotler, P., Caslione, J. (2009), "How Marketers Can Respond to Recession and Turbulence", Journal of Consumer Behavior, Vol.8 (2), pp.187- 191.

[8] Kumar P., Shankar R., and Yadav S. (2008), Flexibility in Global Supply Chain: Modeling the Enablers, Journal of Modelling in Management 3 (3), pp. 277 297.

[9] Kumar, R. (2011), “Consumer Behavior towards Electronic Goods With Reference to Occupational Factors - A Study in Cuddalore Town", International Referred Research Journal, Vol.2 (24).

[10] Long, Mary \& Schiffman, Leon. (2000). Consumption values and relationships: Segmenting the market for frequency programs. Journal of Consumer Marketing.

[11] Nasrudeen .R and Mohamed, "Level of Consumption of Fast Moving Consumer Goods by Rural Consumers - An Analytical Study", International Journal of
Economics, Commerce and Management United Kingdom, Vol. II, Issue 1, ISSN 2348 0386, 2014, pp.1-21.

[12] Perreault, W.D. and McCarthy E.J. (2000), "Essential of Marketing", USA McGrawHill, pp.106-27

[13] Phillips, Diane \& Baumgartner, Hans. (2002). The Role of Consumption Emotions in the Satisfaction Response. Journal of Consumer Psychology.

[14] Rajasekaran, B and Saravanan, P. A. (2014), "Consumer Satisfaction on Fast Moving Consumer Goods", GJRA - Global Journal for Research Analysis, V Vol. 2, Issue 8, ISSN No.: 2277-8160, August 2014, pp.38-41.lume-3, Issue

[15] Rasool, M. S., Rafique, Y., Naseem, M. A., Javaid, S., Najeeb, M., \& Hannan, M. (2012). Impact of Advertisement on consumer Behavior of FMCG Lahore City. Academic Research Journal, pp. 571-574.

[16] Shanmugapriya .G and Sethuraman .R, "Consumers" Satisfaction towards Hamam Soap in Thanjavur Town", International Journal of Engineering and Management Science, Vol.5 (2), ISSN 2229, 2014, pp.122-127 